\title{
Traditional Songket Motifs of Sasak Ethnic Group in Lombok Indonesia Amidst the Society as Examined Through the Concept of Hyperreality
}

\author{
Tomy Taufik Rafiqul Hadi ${ }^{1, *}$ Trie Hartiti Retnowati ${ }^{1}$ Savitri Wukirasih $\mathrm{M}^{1}$ \\ ${ }^{1}$ Graduate School of Art Education, Yogyakarta State University, Yogyakarta, Indonesia \\ *Corresponding author. Email: tomytaufik1@gmail.com
}

\begin{abstract}
This research examines the existence of the traditional songket of the Sasak ethnic group in the context of hyperreality. The traditional songket motifs of the Sasak ethnic group have started to fade and are losing out to the new songket motifs with more popular patterns. Apart from the market effect, the major reason that has caused traditional songket to be rarely made by craftsmen is that the making technique is more difficult than the other types of songket with newer motifs. In this paper the authors employ cultural studies by using Jean Baudrillard's hyperreality theory. This method helps to adjust the objectives and outcomes of the research. As a result, the traditional songket of the Sasak ethnic group is outdone by new, more hyper-realistic motifs. This is also caused by the behavior of the popular masses who are more concerned with current trends than the value of their cultural heritage. Finally, many weavers deconstruct traditional songket motifs into new motifs but still use the names of traditional songket to keep up with the trends and their products sale is ensured.
\end{abstract}

Keywords: Songket, Existence, Cultural Studies, Hyperreality

\section{INTRODUCTION}

Material culture such as songket is meaningful and valuable and social function in Sasak society. However, as time goes by, a culture inevitably has to keep up with developments if it needs to survive. A culture must be able to survive and keep up with the times without killing or eliminating the identity of the culture. Songket as a form of culture in the Sasak ethni group cannot be separated from the influence of the current cultural development. Songket must be preserved to pass the challenges of the times in order to continue to exist. Songket will continue to survive if the fabric can inspire new forms and functions in the cultural structure of society that grows in a culture that has become hyperreal. The original form and function of the songket have been deconstructed into new forms and functions that have created a new form of reality. This new form and function will enable songket to compete with urban culture which has become part of hyperreality, and is supported by the advancement of technology and the growing mass media.

The songket patterns of Sasak ethnic group have undergone a lot of development. The ethnic's songket has a variety of motifs and these motifs are always evolving. The development of songket motifs is also influenced by the popular culture amids the society in hyperreal culture. The urbanites adore the modern versions of songket with their colourful motifs and the shapes of the patterns. This is because the urbanites are the participants in the hyperreal culture. The fashion tastes of these urbanites influence the songket motifs. Mass taste is defined as the standard set by the masses. Therefore, the main factor which causes the development of songket motifs is the fashion taste of the society in regards to hyperreality [6].

The development of patterns of these Sasak songket motifs is resulted from the decreasing popularity of the original, traditional songket motifs of the Sasak ethnic group. These original motifs are 
out done by new motifs. The original motifs can no longer be sourced in the local markets, and customers can rarely obtain songket with original motifs directly from the traditional weavers. Even in the art shops, the modern motifs dominate the displays. Therefore, there is a need to preserve traditional songket motifs from the Sasak ethnic community. By preserving the traditional motifs of Sasak songket, these motifs can be maintained amids developments in the society and the hyperreal context. If no measures are taken to protect these traditional motifs, the motifs will be overcome by the rapidly evolving modern motifs.

\section{LITERATURE REVIEW}

Songket is one of the forms of culture in the form of objects or materials from the Sasak ethnic group in Lombok, Nusa Tenggara Barat. The material culture emphasizes how inanimate objects can be observed in people's actions, and are used for social functions, regulating social relations and giving symbolic meaning to human activities [7]. Culture is always considered a "species" that grows and develops so that the culture can survive [6]. The term hyperreality is to describe how the world is understood by individuals according to their preference for illusory objects rather than original objects, and this is done through modification of cultural objects or icons that are made more attractive than their original form [8].

\section{RESEARCH METHOD}

This research is a qualitative study using a cultural studies approach. The concept of hyperreality can be understood by relating it to contemporary culture because contemporary culture occurs in a hyperreality era, namely after the modern era. Contemporary culture also cannot be separated from the term cultural studies. The author applies a cultural studies approach because this research involves a multidisciplinary field. Cultural studies is always multidisciplinary, or as Barker considers it, postdisciplinary [6]. By using a cultural studies approach, the author can discuss related knowledge and use the knowledge to understand how a social activity takes place. Cultural studies can be considered as a discursive formation, a cluster (or formation) of ideas, images, and practices that provide ways to talk about the formation of knowledge and connect with certain topics, social activities, or institutions in society [6]. By using this approach, it can be understood that cultural studies is a highly complex science.

The Sasak ethnic culture in the form of songket motifs will continue to develop in accordance with the times and the community. Therefore, to study a culture that continues to develop such as this songket motif, a research approach that continues to develop is needed. The development of contemporary culture always presents novelties that must be understood from the perspective of the latest studies [6]. Therefore, cultural studies which has a multidisciplinary nature, and this approach is considered to be always able to have relevance or conformity with the latest socio-cultural developments in contemporary society in the context of hyperreality. The cultural studies approach has become a way of thinking that tends to combine existing theories and methods by adjusting to the needs in observing contemporary phenomena [6]. Therefore, using cultural studies would be very suitable to study the existence of traditional songket motifs in hyperreality culture in the midst of society, because people who live in this contemporary era are participants of hyperreality culture.

Cultural studies approach has developed and is heavily influenced by postmodernism, which is a movement in understanding existing social and cultural realities. The postmodern cultural phase, the issues raised shifted towards various issues that have become the subject matter of the postmodernism movement itself [6]. There are a variety of popular issues including issues of genesis, sign productivity, sign play, free interpretation play, the relativity of desiring machine knowledge, heterogeneity, hyperreality, and the nomadism of the relationship between knowledge and power (genealogy), and discourse theory (discourse) [6]. At this stage, cultural studies is influenced by "poststructuralist" and "postmodernist" thinkers, "poststructuralist" thinkers such as Derrida, Barthes, Kristeva, while postmodernist thinkers such as Foucoult, Deleuze, Guattari, Lyotard, and Baudrillad as suggested by Piliang \& Jejen [6].

Based on the previous discussion, in this paper the writer will use the hyperreality theory of Jean Baudrillad to study the existence of traditional Sasak ethnic songket motifs in the context of hyperreality culture. Hyperreality is the creation of real models or the creation of models without origin or origin or distracted from reality [6]. Hyperreality is more of a response to certain conditions that occur in the body, nature and culture [3]. There is a world that reproduces, grows, moves, and changes without purpose (fatality), without foundation (antifoundation), without control, without code (social code), and has no meaning (meaningless). In the context of hyperreality, this causes originality to become blurred, and any event can arise without root or origin, without stability, and even without certainty [6]. Hyperreality is a world that refers to itself and emerges on its own.

This state of hyperreality has caused hyperreality consumption behaviours in society. The state of hyperreality has made modern society become excessive in the pattern of consuming material objects or immaterial things that have no clear value [1]. Modern consumption involves externally 
manipulating signs and that consumption lacks the symbolic values involved in the process of creation [2]. Poverty is not only about the quantity of goods owned by a group, but also the relationship between these goods and humans. This kind of consumption behavior where people own many goods leads people to believe that they are rich, satisfied, happy, and liberated. In fact, they are degrading themselves and their own culture because they tend to consume what they want not what they need [2]. Consumer culture uses images, signs and symbolic objects, desires and fantasies that emphasize romantic authenticity and emotional fulfillment in pleasing oneself and not the other people [4]. It can be emphasized by those who emphasize the novelty and historical events which are admittedly brought about by post-modernism where we enter a phase in which the old cultural hierarchy becomes obsolete [4]. Many things have lost their essence because it is the market that determines their value. This development has led to people's preference for following the existing trends instead of upholding their own values and culture [9].

\section{FINDINGS}

\subsection{Songket}

Songket is a form of culture created by humans. Koentjaraningrat suggests that at least culture has 3 forms and one of these cultural forms is a form of culture as objects made by humans, and songket is a form of culture produced by humans [9]. Songket has various meanings depending on the place or area the songket is located in. Jes A. In Timor songket cloth is called sotis cloth, which is a woven fabric made with the weft technique that produces embossed ornaments, sotis in Timorese means hooking or prying up the rotting threads that have been arranged on a loom [5]. Songket cloth is a fabric made with a woven base of cotton, half silk or silk which always has a variety of decorations [5]. Songket is adding colored weft threads or made of metal without breaking [5]. Suwaati Kartika also argues that the principle of adding threads is called songket because it is connected with the process of tipping the threads of function in making decorative patterns [5]. In Lombok itself what is meant by songket is a cloth that has embossed decorations made of cotton thread, gold thread or silver thread [5]. Meanwhile, according to the local language, songket means embroidering using gold or silver threads [5]. Based on the information above, we can conclude that the songket cloth is a fabric made by weaving techniques which has a variety of decorations that arise and are made of cotton, silver and gold threads.

In the Sasak ethnic community, songket is only used during traditional wedding events or other sacred traditional events. The Sasak ethnic community songket is used as men's or women's clothing during traditional ceremonies or as bridal attires [5]. Songket has several different names which also have different functions such as bendang, selewoq, dodot or leang, bendang belt or anteng belt, and bebet. Selewoq (shawl), dodot or leang (male head scarf / headband), and bebet (belt) are only used by men, while for bendang (shawl), and bendang belts or anteng belts (belts / shawls) are only worn by women [5]. Therefore, in the Sasak ethnic community songket already has very complex functions and benefits and there are already rules for its use, depending on its forms. This is because songket is not only limited to its physical form, because behind this physical form there are things that are non-physical. Behind the physical form of a songket cloth, it contains an implied non-physical meaning or value that affects the origin of the process of making a Lombok songket cloth such as historical background, customs, fabric material, production process, and art [5]. This has made songket not only a fabric, but also a sacred cultural identity and highly respected by the Sasak people.

As with various types of songket fabrics in other areas, the songket of the Sasak ethnic community also has various kinds of motifs. These motifs are inspired by various forms or objects, such as flora and fauna. But in songket culture, the Sasak ethnic community has more floral motifs. This is due to the strong influence of Islam on the Sasak ethnic group which prohibits the visualization of living things. Because of this, motifs based on flora and geometric shapes such as subahnale motifs were created. In the case of decorative arts, Islam prohibits animate creatures such as animals and humans from being used as decoration, so that the subahnale songket was created [5]. In addition to the subahnale motif, songket cloth also has several other types of motifs named as bintang empet, ragi genep, serat penginang, kembang komak and wayang (shadow puppets characters). The Sasak ethnic songket motifs have several kinds of patterns named as bintang empet, bintang sambrah, payung agung (the grand umbrella), taman rengganis, subahnale, remawe, taman barong, and serat penginang [5]. All of these songket motifs are traditional motifs of which existence is increasingly threatened, slowly starting to sink under the new motives. Most of these motifs are inspired by flower shapes, geometric shapes, and star shapes which are then combined and matched together to form a beautiful songket motif. The songket subahnale motif is in the form of many geometric hexagons that cover the area of the cloth, then the inside of the hexagon is decorated with decorations named kembang remawa, tanjung (lotus), and panah (arrows), and the edges of the cloth are decorated with decorations of kuta mesir (rhombi patterns) [5]. As for the new motifs as reported by Inaq Ahmadi (53), there are various motifs, namely subahnale klentang, kacang, keker, 
bunga mawar, keker, serat penginang with new patterns, and there are more new motifs made by songket weavers that even they themselves cannot identify the types of motifs they produce as long as the patterns are attractive.

These motifs are not only combinations of geometric shapes with flora, fauna, or humans, but there are also motifs that only consist of geometric shapes such as the serat penginang motif. The serat penginang motif is in the form of a rectangular geometric pattern which resembles the projection image of the betel box and then the inside of the rectangle is decorated with other motifs named as bintang (stars), tapak dara (periwinkle), and diagonal lines, and on the edges of the fabric, these parts are decorated with meander patterns as in the kuta mesir (rhombi) motifs [5]. Apart from subahnale and serat penginang motifs, other motifs are also a combination of flora, fauna, human, and geometric shapes. It is as if all these parts were tied together and inseparable.

\subsection{Traditional Songket Motifs amids the Society as Examined through the Concept of Hyperreality}

The discussion about the existence of the traditional Sasak ethnic songket motif in the context of hyperreality cannot be separated from popular culture. Popular culture is also inseparable from mass culture, the term mass culture is often equated with popular culture [6]. This is because the word "popular" also refers to the meaning of "the common people." The word "mass" can be interpreted as low, cheap, general vulgar, or the average [6]. Mass refers to the common people. Mass culture as the culture of the common people which is built on the aesthetic standards, tastes and intellectuals of the majority, as well as low standards. , the existence of traditional songket motifs in the context of hyperreality that is inferior to these new, more popular motives shows that the public or popular masses have low standards and tastes for a songket motif [6]. This is because the new songket motifs are not related to philosophical values. at all, and this contrasts with the traditional songket motifs rich in moral values that lead to a feeling of pride and dignity if someone wears or owns it.

Mass culture is also related to industrial culture. Mass culture is also often called industrial culture [6]. Industrial culture cannot refuse speculation about the consciousness and unconsciousness of millions of masses of whatever is directed at them, mass is not the main factor but a secondary object that is calculated and then become part of the machine [6]. The ideology of mass culture articulates the view that pop culture is a product of capitalist production and, therefore, pop culture is the subject of the laws of capitalist market economy [6]. The impact of this capitalist market results in degraded products but still generates large profits. This is what greatly influences the existence of the traditional songket motifs of the Sasak ethnic group in the context of hyperreality and these motifs are degraded because these traditional motifs are inferior to the new motives that are preferred by most people but the new motives do not see sacred moral values such as those contained in the traditional Sasak ethnic songket motifs.

This popular culture ultimately requires people to have a popular mindset in which there is also a public mindset that shows a tendency towards hyperreality. This popular mindset causes the public or the masses to choose appearance over substance, seeing things from the surface rather than observing them with depth of thinking, prioritise pleasure over knowledge, and tend to think about using shortcuts [6]. These factors cause the masses to not appreciate the process of creating a songket motif. They become less appreciative of their own culture, because for the popular masses what is crucial is that they exist, thus, ignoring their cultural values. This causes the masses to not really care whether what they are using is traditional songket motifs that have sacred values or new motives that have no value, the masses ultimately do not consider whether the songket they use comes from their own culture or people's culture. In addition, the masses also no longer pay attention to whether the songket cloth they used is really traditionally woven or just cloth printed using the songket motif.

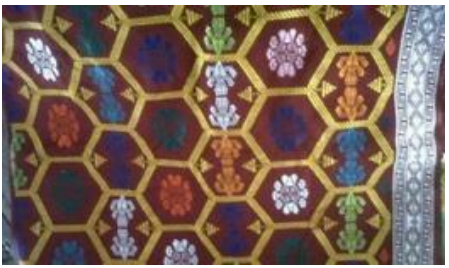

Figure 1. The original motif of subahnalae

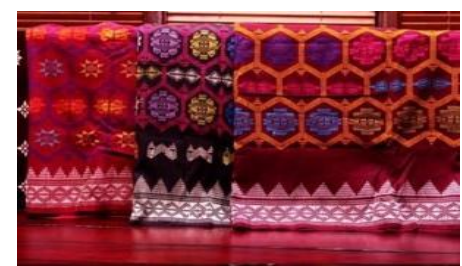

Figure 2. The original motif of subahnalae

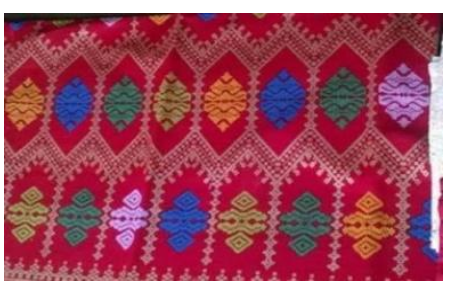

Figure 3. The motif of subahnale klentang which is a new pattern of the subahnale motif 


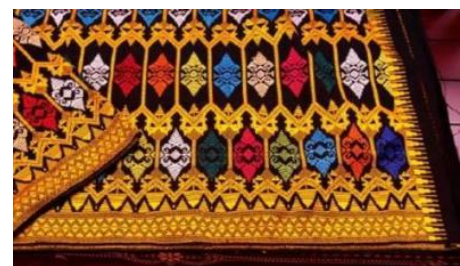

Figure 4. The motif of subahnale klentang which is a new pattern of the subahnale motif

The motifs presented above are a form of the traditional subahnale motif that has been developed into the subahnale klentang motif. From the picture, the difference between the original subahnale motif and the subahnale klentang motif can be clearly observed and there is the most striking difference, namely the subahnale klentang motif has larger and more spaced patterns than the original subahnale motif. The original subahnale motifs have a denser and more complex shape. As stated by Papuk Par (89), this motif is called subahnale because of the difficulty level in making this motif, so in the past the weavers who made it said the word Subhanallah when making this motif. The same argument is also presented by Inak Ahmadi (53) and Amaq Mustafa (47). The existence of the original subahnale motif is now inferior to the subahnale klentang motif. Therefore, the author can conclude that from field observations of the weavers and art shops in Sukerare Village, the original motifs are less popular than the new ones.

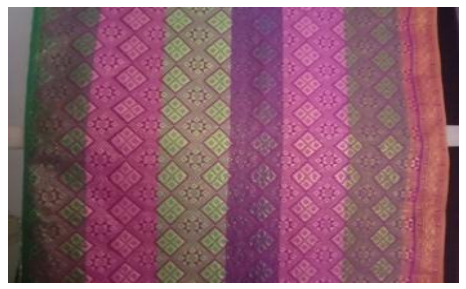

Figure 5. The original motif of serat penginang

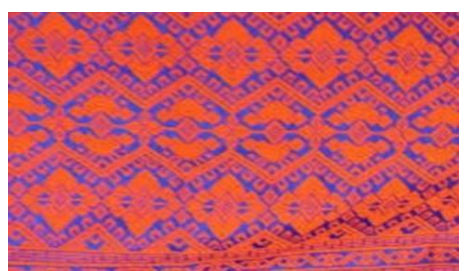

Figure 6. The new motif of serat penginang

From the examples of the motif images above, there is a very striking difference between the original penginang fiber motif and the new serat penginang motif. The original pattern looks neater and the size of the pattern is smaller and the dominant motif is geometric shapes such as rhombus. Meanwhile, the new pattern has larger patterns with the shape obtained by rhombic stylization. According to Papuk Par (89), the name of the serat penginang motif comes from a motif inspired by the form of penginang (the betel box of the Sasak people).
Similar to the subahnale motif, the existence of the penginang fiber motif is also less popular than its new form.

\section{CONCLUSION}

The existence of the traditional Sasak ethnic songket motif is increasingly threatened in contemporary culture because the tastes of the people, especially the Sasak people, are increasingly following trends in the context of hyperreality. This is because the life of the popular masses tends to prioritize trends over philosophical depth and utility value. This causes people to have a low taste for a cultural product. They did not see whether the songket motif they choose has been designed based on the traditional motifs of Sasak ethnic songket. For the majority of consumers, their priority is to be seen wearing songket cloth, regardless of whether the songket cloth is the original Sasak ethnic songket woven cloth or only cloth that uses a Sasak ethnic songket motif. Most members of the Sasak ethnic community prefer cheaper prices. The most important thing for them is to be able to have Sasak ethnic songket cloth, even though they do not understand and do not know whether the songket cloth they buy is a product of their own culture or another culture. The mindset of the popular community about the Sasak ethnic song cloth must be changed immediately so that the existence of the traditional songket motif is maintained in the context of the hyperreality of the popular masses. In addition to the people's mindset, the price of traditional Sasak ethnic songket cloth which is too expensive and the number of weavers who can make traditional Sasak ethnic songket motifs also decreases the existence of the traditional Sasak ethnic songket motif. These factors make art shops rarely provide traditional songket motifs and there are fewer young weavers who know and are able to make traditional Sasak ethnic songket motifs. This causes the traditional songket motif to feel foreign to the Sasak ethnic community itself and make new motifs even more popular. In addition, there are several motifs that have changed patterns, such as the subahnale klentang, wayang, and serat penginang, and there are also motifs that can be found again such as taman rengganis garden, taman barong, and remawe motifs. Therefore, it is important that there is an effort to continue promoting of traditional Sasak ethnic songket motifs to the community and the younger generation. Efforts to make traditional Sasak ethnic songket motifs become teaching materials for decorative materials on Cultural Arts subjects in schools in Lombok are also deemed necessary. That way, the existence of the traditional songket motifs of the Sasak ethnic group will be maintained and not continue to exist within the hyperreal masses. If the Sasak ethnic community continues to choose new songket motifs, the Sasak people will forget the traditional songket motifs that have become their 
cultural identity. The moral values that exist in the form of traditional Sasak ethnic songket motifs which can become knowledge and traditional heritage for the next generation will also disappear. The next generations will not recognize the traditional songket motif patterns of the Sasak ethnic group because of the tendency towards hyperreality that is increasingly out of control. The Sasak ethnic community will be unaware of how rich the cultural values the community once had. They will only recognize new songket motifs that only sell well in the market but have no moral values at all. Therefore, maintaining the existence of this traditional Sasak ethnic songket motif by continuing to introduce it to the community and the younger generation so that these traditional motifs can be preserved is a necessary step.

\section{REFERENCES}

[1] Azwar, Muhammad. Teori Simulakrum Jean Baudrillard dan upaya pustakawan mengidentifikasi informasi realitas [Jean Baudrillard's Simulacrum Theory and the librarian's efforts to identify information on reality]. Khizanah al-Hikmah: Jurnal Ilmu Perpustakaan, Informasi, dan Kearsipan 2.1 (2014): 38-48.

[2] Baudrillard, Jean, Wahyunto, and George Ritzer. Masyarakat konsumsi. [The consumption society]. Kreasi Wacana, 2004.

[3] Cempaka, Putri Surya, and Johannes Haryatmoko. Hyperreality among defense of the ancients 2 's players. Jurnal Komunikasi Indonesia (2019): 225-234. DOI: https://doi.org/10.7454/jki.v7i3.9678

[4] Featherstone, Mike. Posmodernisme dan budaya konsumen. [Postmodernism and consumer culture]. Pustaka Pelajar, 2001.

[5] Handayani, Indah dkk. Kain Songket Lombok [Lombok's Songket Fabric], Mataram: Depdikbud. 2000.

[6] Piliang, Yasraf Amir, and Jejen Jaelani. Teori budaya kontemporer: penjelajahan tanda dan makna [Contemporary cultural theory: the exploration of signs and meanings]. Yogyakarta: Aurora (2018).

[7] Pradoko, S. Paradigam-Paradigma Kualitatif untuk Penelitian Seni, Humaniora dan Budaya [Qualitative Paradigms for Arts, Humanities and Cultural Research]. Yogyakarta: Charissa Publisher (2017).

[8] Torikian, G. J. Against a Perpetuating Art From Hyperreality. The Journal of Aesthetic Education. 2010.
[9] Weiss, Martin. Reality, Simulation and Hyperreality: An Essay on Baudrillard. International Journal of Baudrillard Studies 8.2 (2011). 